\title{
DISPUTAS SIMBÓLICAS ENTRE CATÓLICOS E ESPÍRITAS NO PRIMEIRO CENTENÁRIO DO ESPIRITISMO
}

\author{
SYMBOLIC DISPUTES BETWEEN CATHOLICS AND \\ SPIRITUALISTS IN THE FIRST CENTENARY OF SPIRITUALISM
}

\author{
Marilane Machado \\ Doutoranda da Universidade Federal do Paraná \\ E-mail: marilanemac@ig.com.br
}

\begin{abstract}
RESUMO: Neste artigo procuramos demonstrar parte da relação conflituosa entre catolicismo e espiritismo no contexto do primeiro centenário espírita. Tais conflitos são evidenciados através da análise de discursos católicos publicados na Revista Eclesiástica Brasileira no ano de 1956, quando foi anunciada a Cruzada de Defesa da Fé Católica no I Centenário do Espiritismo, que ocorreria no ano seguinte. Compreendemos esta relação de disputas simbólicas como integrante da dinâmica do campo religioso brasileiro na segunda metade do século $\mathrm{XX}$, sendo que ao publicar discursos religiosos contrários às práticas espíritas a Igreja Católica construía representações acerca do espiritismo que podem ser apreendidas através dessas publicações.
\end{abstract}

PALAVRAS-CHAVES: Religiões e Religiosidades. Espiritismo. Igreja Católica.

\begin{abstract}
The aim of this article is to demonstrate part of the conflictual relationship between Catholicism and Spiritualism, in the context of the first spiritualist centenary. Such conflicts are evidenced through the analysis of catholic discourses published in the Brazilian Ecclesiastical Magazine in 1956, when the Crusade for the Defense of Catholic Faith in the First Centenary of Spiritualism was announced, which would occur in the following year. This relationship of symbolic disputes is understood as part of the dynamics in Brazilian religious field during the second half of the twentieth century. Thus, when publishing religious discourses contrary to spiritualistic practices, Catholic Church built representations about Spiritualism that can be seized through these publications.
\end{abstract}

KEYWORDS: Religions and Religiosities. Spiritualism. Catholic Church.

\section{Introdução}

Neste artigo propomos uma reflexão acerca do contexto histórico do início da segunda metade do século XX no Brasil no que diz respeito ao campo religioso e às disputas simbólicas envolvendo a Igreja Católica e o Espiritismo. Buscamos assim subsídios para a compreensão da necessidade que o espiritismo tinha de se afirmar no campo religioso brasileiro, enquanto a Igreja Católica buscava assegurar o espaço já conquistado neste campo num contexto em que se sentia ameaçada pelo avanço de outras denominações religiosas.

Oficina do Historiador, Porto Alegre, EDIPUCRS, v. 7, n. 2, jul./dez. 2014, p. 62-79. 
Para a realização desta proposta analisaremos artigos publicados na Revista Eclesiástica Brasileira (REB) a respeito do centenário do Espiritismo e suas comemorações no Brasil, compreendendo que este momento é significativo para a compreensão das disputas simbólicas no campo religioso brasileiro. Entendemos o conceito de campo a partir da definição de Pierre Bourdieu, como sendo um universo relativamente autônomo de relações específicas que podem ser observadas entre os atores sociais. O que determina essas interações é a posição que cada um (instituição ou indivíduo) ocupa dentro da estrutura de cada campo (BOURDIEU, 1989, p.66-67). O lugar ocupado por esses atores sociais em cada campo difere conforme a posse de determinados capitais simbólicos exigidos dentro deles e a troca dos bens simbólicos entre os integrantes do campo. A posse dos bens simbólicos confere poder aos atores sociais que compõem o campo. Pensar em campos, portanto, é pensar no poder simbólico existente em cada um deles e no que significa a noção de poder para Bourdieu.

Seguindo esta perspectiva, busca-se a compreensão dos discursos publicados na REB partindo do pressuposto que o poder não está na palavra, em si, mas nos sentidos e representações criadas por elas e no reconhecimento que uma população de fiéis confere a um porta-voz autorizado, detentor do capital simbólico legítimo para o grupo (BOURDIEU, 1996, p. 89-91). O porta-voz autorizado, tem legitimidade sobre o grupo na medida em que seu discurso é reconhecido.

Também faz-se importante para esta análise o conceito de representação tal como o compreende Roger Chartier. Para o autor, o principal objeto da história cultural deve ser o entendimento de como uma realidade social é construída. Tal entendimento se dá através das representações que se criam dessa realidade. Estas são sempre determinadas pelo interesse do grupo que as forjam e se manifestam por meio de discursos que nunca são neutros, pois "produzem estratégias e práticas (sociais, escolares, políticas) que tendem a impor uma autoridade à custa de outros, por elas menosprezados, a legitimar um projeto reformador ou a justificar, para os próprios indivíduos, as suas escolhas e condutas.” (CHARTIER, 1985, p.17). Assim, as representações estão sempre colocadas num campo de luta, de concorrências pelo domínio do poder. 


\title{
Uma revista do Clero, feita pelo Clero e para o Clero
}

Em 1930 a Editora Vozes solicitou a permissão do Cardeal do Rio de janeiro, Dom Sebastião Leme da Silveira Cintra, para realizar o projeto da criação de uma revista. Dom Sebastião aceitou a proposta e anexou a ela o Boletim Arquidiocesano do Rio de Janeiro, tornando a sua assinatura obrigatória para o clero. A revista, publicada a partir de janeiro de 1939 com o nome de COR e com o subtítulo Revista Eclesiástica Brasileira, foi considerada um órgão eclesiástico (ANDRADE, 2008, p.88).

COR não teve a projeção nacional esperada, diante disso foi definida uma reformulação e a criação de uma nova revista, que ficaria sob responsabilidade administrativa da Editora Vozes Limitada, ficando escolhido para título o de Revista Eclesiástica Brasileira (ANDRADE, 2008, p.89). A responsabilidade pela redação do periódico ficou a cargo da Província Franciscana da Imaculada Conceição do Brasil, através do Instituto Teológico Franciscano de Petrópolis, Rio de Janeiro (DALMOLIN, 2010, p.17).

Em janeiro de 1941 saiu o último fascículo da COR e em março do mesmo ano apareceu a REB. O Frei Tomás Borgmeier era diretor da Editora Vozes e foi o fundador da REB em 1941 (ANDRADE, 2008, 92), seu objetivo com a nova publicação era o de ser uma revista eclesiástica sintonizada com um Brasil católico, que fosse capaz de levar o ideal do catolicismo por toda a parte do território nacional:

\begin{abstract}
Visamos bem alto, confiantes na graça de Deus. A "Revista Eclesiástica Brasileira" pretende colocar-se ao nível das grandes revistas eclesiásticas de outros países. Tal pretensão não deve parecer atrevimento. O Brasil é, em catolicidade, dos primeiros países do mundo. $\mathrm{O}$ nosso mal foi sempre desconhecer as nossas coisas. Neste vasto país, onde o catolicismo prospera em todos os setores, seria inconcebível que este progresso se efetuasse sem guias espirituais à altura do seu mandato. $\mathrm{O}$ Brasil os possue, e grandes. $\mathrm{O}$ que faltava apenas era arregimentar as personalidades e as capacidades em evidência, coordenar os coeficientes da nossa cultura eclesiástica. (REB, 1941, p.1)
\end{abstract}

A REB é, desde sua criação, uma publicação trimestral (com fascículos publicados nos meses de março, junho, setembro e dezembro) voltada para o clero católico, é utilizada como meio de publicar documentos oficiais, além de textos relacionados a assuntos de interesse da Igreja Católica e assim padronizar o discurso do clero. Enfatizava-se que as ideias propagadas

Oficina do Historiador, Porto Alegre, EDIPUCRS, v. 7, n. 2, jul./dez. 2014, p. 62-79. 
na revista não deveriam circular somente entre os membros do clero, mas atingir a toda a comunidade católica do país, propagando os princípios defendidos pela instituição:

\begin{abstract}
A ideia da revista obedeceu ao lema: revista do clero, feita pelo clero, para o clero. Se ela houver de atingir plenamente o seu objetivo, não deverá limitarse a ser para o clero. Há de ser feita pelo clero, auscultada aos desejos dele. Cumpre, portanto, que o mesmo clero a considere sua, que a sufrague com sua inteligência, que lhe mande artigos e comunicações científicas, que aborde nela questões pastorais e pontos de vista de atualidade. A vida é sempre um jogo de dar e receber: o coração ejeta sangue, e sangue torna a receber. O pensamento publicado frutificará em outrem; suscitando novos pensamentos; não publicado permanece estéril. (REB, 1941, p.2)
\end{abstract}

O Frei Tomás Borgmeier permaneceu como redator da revista de 1941 até 1952 (ANDRADE, 2008, p.89). Durante este período encontramos somente um artigo especificamente relacionado ao espiritismo, no ano de 1941, no volume 1, fascículo 3 da revista, assinado pelo Padre Vicente M. Zioni, professor no Seminário Central em Ipiranga, São Paulo. Em seu texto intitulado Causa dos fenômenos espíritas o padre combatia o espiritismo relacionando diversos fenômenos espíritas, qualificando-os como fraudulentos e dando a eles explicações naturais. Aos fenômenos que não podiam ser explicados naturalmente o padre dava uma explicação católica relacionada à demonização.

Entre 1952 e 1971 o redator da REB foi o Frei Boaventura Kloppenburg (SCHLENKER, 2011). A partir do ano de 1952 encontramos diversas publicações a respeito do espiritismo em todos os volumes da REB até o ano de 1961, quando os esforços e publicações voltaram-se para a realização do Concílio Vaticano II, que iniciou em 1962 e terminou em 1965. A maioria dos textos publicados na REB sobre o espiritismo neste período são de autoria do próprio redator, o Frei Boaventura Kloppenburg, todos demonstrando uma visão totalmente contrária e condenatória ao espiritismo.

Entre 1972 e 1986 o redator da REB foi o Frei Leonardo Boff, neste período a revista se caracteriza pela divulgação das bases da Teologia da Libertação. Desde 1986 a REB tem como redator o Frei Elói Dionísio Piva e apresenta um caráter ecumênico e eclesial (SCHLENKER, 2011).

Interessa-nos especialmente as publicações da REB desde a sua criação, em 1941, até o ano de 1965, quando se encerrou o Concílio Vaticano II. Neste período é a notória a propagação de discursos católicos a respeito do espiritismo, nos quais podemos perceber as

Oficina do Historiador, Porto Alegre, EDIPUCRS, v. 7, n. 2, jul./dez. 2014, p. 62-79. 
representações acerca da doutrina espírita elaboradas pela oficialidade católica e divulgadas na revista através dos discursos de membros do clero. Esses discursos demonstram também um conflito latente no campo religioso brasileiro entre a Igreja Católica e outras instituições e doutrinas religiosas, interessando para nós especialmente os conflitos entre catolicismo e espiritismo. Para este ensaio especificamente selecionamos alguns textos publicados na REB relacionados ao centenário do espiritismo, ocorrido em 18 de abril de $1957^{1}$. Na ocasião, o redator da REB, Frei Boaventura Kloppenburg, foi também o maior propagador de ideias contrárias ao espiritismo nas páginas da revista.

\section{O centenário do espiritismo através das páginas da REB}

No ano de 1952 ocorreu a organização da Conferência Nacional de Bispos do Brasil (CNBB), órgão institucional que representava e centralizava as decisões do clero brasileiro, uniformizando as ações que eram organizadas para manter a hegemonia católica (COSTA, 2001, 142). Na primeira reunião ordinária da CNBB, realizada em Belém do Pará entre 17 e 20 de agosto de 1953 foi ordenado ao Secretariado Nacional de Defesa da Fé e da Moral que se realizasse uma campanha contra o espiritismo e foi nomeado como chefe da sessão antiespírita o Frei Boaventura Kloppenburg, que já vinha publicando artigos contra o espiritismo na Revista Eclesiástica Brasileira (REB, 1956, p.421-22).

Compreendemos assim, que o Frei Boaventura Kloppenburg passa a ser um porta-voz autorizado do clero brasileiro contra o espiritismo. O conceito de porta-voz autorizado é desenvolvido por Pierre Bourdieu e entendemos ser um conceito importante para este estudo. Para Bourdieu, o porta-voz autorizado tem poderes plenos para falar e agir em nome do grupo que o instituiu. Ele personifica o grupo "dando assim um corpo biológico a um corpo constituído" (BOURDIEU, 1996, 82-3). Somente o fato de ser sagrado frei já fazia dele um porta-voz do clero a respeito de assuntos que diziam respeito à Igreja Católica, ao ser novamente instituído pela CNBB como chefe da sessão antiespírita, o poder de falar em nome do grupo contra o espiritismo tornou-se ainda mais legítimo. A campanha do Frei

\footnotetext{
${ }^{1} 18$ de abril de 1857 foi considerada a data da fundação do espiritismo, a partir da publicação de $O$ Livro dos Espíritos, que trouxe pela primeira vez elementos filosóficos da nova doutrina. Os espíritas consideram que $O$ Livro dos Espíritos, como o próprio título já sugere, é obra de Espíritos evoluídos que o revelaram a Allan Kardec, que foi então, o codificador da nova doutrina.
}

Oficina do Historiador, Porto Alegre, EDIPUCRS, v. 7, n. 2, jul./dez. 2014, p. 62-79. 
Kloppenburg contra a doutrina que classificava de herética seguiu nas páginas da revista até as vésperas do Concílio Vaticano II, quando um discurso mais respeitoso em relação ao pluralismo religioso pareceu ganhar força.

No ano de 1956, no fascículo 2 publicado no mês de junho, o Frei Boaventura Kloppenburg publicou uma comunicação sobre o primeiro centenário do espiritismo, que ocorreria no ano seguinte. Na comunicação, demonstrava a preocupação de que a Igreja se mobilizasse em relação ao centenário, que já vinha sendo divulgado pelos representantes espíritas em seus periódicos, na intenção de gerar uma série de comemorações nesta data, a programação do centenário publicada pela Federação Espírita Brasileira no jornal espírita Reformador foi transcrito nas páginas da REB e escreveu o Frei Kloppenburg:

Tornamos a recordar que a finalidade de todos esses festejos é, segundo o próprio texto, "divulgar o máximo possível a obra kardekiana", para kardekizar o Brasil, para propagar entre os católicos do Brasil que é bom e lícito evocar os mortos ou espíritos, para difundir entre os nossos fiéis que Cristo não é verdadeiramente Deus, que Jesus não instituiu Igreja alguma nem determinou meios de santificação (sacramentos), que esta nossa atual vida terrestre não é definitiva, que haverá outras vidas e novas oportunidades para se conseguir a perfeição, que o inferno não existe, etc.

Percebe-se neste primeiro comunicado a respeito do centenário do espiritismo um campo de disputas simbólicas bastante intensas. A Igreja Católica, através das palavras de seu porta-voz, reivindicava a legitimidade de seus dogmas e doutrina desqualificando o espiritismo, demonstrando receio de que a doutrina de Kardec se dissipasse e que fiéis católicos enveredassem para o espiritismo. Essas disputas simbólicas ficaram ainda mais intensas pelo fato de que as datas das comemorações do centenário espírita organizadas pela Federação Espírita Brasileira, que aconteceriam de 13 a 18 de abril, naquele ano coincidiriam com os primeiros dias da Semana Santa, datas muito significativas para a Igreja Católica.

Diante do exposto, ainda no ano de 1956, no fascículo 4 do volume XVI da REB, Kloppenburg anunciava uma Cruzada de Defesa da Fé Católica no I Centenário do Espiritismo.Neste texto expunha novamente as intenções de comemoração por parte dos espíritas no intuito de mobilizar seus leitores para uma ação coletiva contrária ao espiritismo nesta ocasião. 
Não queremos agora discutir se é feliz ou infeliz a coincidência das comemorações espíritas com a Semana Santa. Será um fato com o qual haveremos de conformar-nos. Nem nós católicos poderemos transferir esta santa e tradicional semana para outros dias, nem os espíritas hão de renunciar às solenidades naqueles dias fixados pelo centenário. (REB, 1956, p.827)

Diante desta constatação da importância simbólica das datas para ambos os grupos o frei passou a defender a legitimidade da comemoração dos católicos, como verdadeiros seguidores de Cristo, reverenciado durante a Semana Santa, enquanto desqualificava os espíritas ao expor que a comemoração daquele grupo colocaria Kardec no centro das atenções, adjetivando o personagem como autêntico anticristo. Diante disso, apresentou uma proposta de mobilização dos católicos durante a semana santa:

Com prudência pastoral e caridade, mas com simplicidade e clareza, poderemos, na próxima Semana Santa, aproveitando também nós o ensejo do centenário espírita e a coincidência das comemorações com a mais sagrada das nossas semanas, esclarecer o nosso povo católico sobre a verdadeira finalidade do Espiritismo, sobre o caráter herético e anticristão da doutrina kardecista, sobre a blasfema e pagã filosofia reencarnacionista, sobre a gravidade do pecado da necromancia, da magia e das superstições. (REB, 1956, p.828)

Como proposta de ações concretas para a semana o Frei Boaventura indicava que seriam distribuídas em todas as paróquias e colocadas á disposição para aquisição junto à Editora Vozes um programa com sugestões, alocuções radiofônicas, artigos, orações, etc. a serem realizadas nas datas da semana santa. Anexado ao fascículo 4 da REB, de dezembro de 1956, um denso suplemento trazia todo o plano de ação para a semana santa, na apresentação do material, o Arcebispo de Porto Alegre, Vicente Scherer, Presidente do Secretariado Nacional da Defesa da Fé e da Moral da CNBB realizou a apresentação do material agradecendo, em nome do clero brasileiro, ao Frei Boaventura Kloppenburg pela dedicação à luta contra o espiritismo:

O clero brasileiro, certamente, ficará muito agradecido ao infatigável Pe. Frei Boaventura que, conhecedor, como talvez ninguém entre nós, dos erros do espiritismo, com mais esta publicação, oferece aos colegas no sacerdócio precioso auxílio para o eficaz cumprimento de um dever urgente e 
sacrossanto, Deo gratias! (REB, Suplemento do fascículo de dezembro de 1956, p.5)

No fascículo propunha-se que no período de 01 a 13 de abril de 1957 esforços fossem voltados para a parte da defesa da fé e esclarecimento dos católicos sobre o Espiritismo, recorrendo a todos os meios e órgãos de publicidade e propaganda possíveis, principalmente à rádio, ao jornal, ao livro e ao folheto, assim como fariam os espíritas. Diante disso, recomendava-se que os sacerdotes reservassem com a rádio emissora local um programa diário de 30 minutos, de 01 a 13 de abril, totalizando 13 programas cujos textos completos seriam fornecidos. Salientava-se que, caso o dono da emissora se recusasse a permitir a irradiação das 13 alocuções, lembrassem a ele da possibilidade de se conseguir algum benevolente patrocinador católico.

O jornal local também deveria ser mobilizado nos mesmos dias e os textos das alocuções radiofônicas poderiam ser adaptados para o meio impresso. Recomendava-se ainda a propaganda através de folhetos, estando à disposição pela Editora Vozes os folhetos com os seguintes títulos: Por que o católico não pode ser espírita, o Católico perante a Umbanda e Por que não Admito a Reencarnação. Orientava-se, por fim, que as livrarias locais fossem acionadas para adquirirem obras de orientação católica sobre o espiritismo e uma lista de obras recomendadas foi incorporada ao material, assim como todos os textos dos programas radiofônicos, textos de rádio teatro e textos para publicação em jornal.

De 14 a 18 de abril, a Semana Santa e semana do centenário espírita, seria o ápice da campanha contra o espiritismo. Para o Domingo de Ramos esperava-se que os fiéis fossem conclamados a comparecer na Procissão de Ramos em número maior que o comumente esperado. Acreditava-se que neste dia, com orações mais fervorosas, acentuando-se a divindade de Cristo os fiéis estariam naturalmente se colocando contra a propaganda espírita, já que para os idealizadores da campanha os espíritas eram contrários à crença na divindade de Cristo.

Para a segunda, terça e quarta-feira santas não há funções litúrgicas específicas, mas já que os espíritas fariam grandes e solenes manifestações nestes dias, os católicos o transformariam num tríduo de orações e súplicas. Os fiéis deveriam ser convocados às Igrejas em um horário mais apropriado para realizar orações diante do Santíssimo "Pedindo a Deus a conservação na verdadeira fé, reparando as injúrias feitas pelos espíritas à pessoa e à obra redentora de Cristo e suplicando a conversão de todos os caríssimos irmãos que de nós se 
apartam por causa do Espiritismo.” (REB, Suplemento do fascículo de dezembro de 1956, p.125) Para esses dias o fascículo também trazia sugestões de orações e textos a serem publicados em rádio ou jornais impressos.

Para o dia 18, a data exata do Centenário Espírita que coincidiria com a Quinta-feira Santa, recomendou-se que todos os membros de Associações Religiosas deveriam fazer um juramento antiespírita, sob pena de exclusão da respectiva Associação. O Secretariado Nacional de Defesa da Fé havia mandado imprimir na Editora Vozes um folheto especial contendo o texto da Profissão de Fé e do juramento, que seriam lidos num momento apropriado da celebração eucarística. $\mathrm{O}$ folheto deveria ser adquirido previamente para que cada associado o assinasse e para que posteriormente fosse arquivado na respectiva Associação. Seria o desfecho solene da Cruzada contra o Espiritismo em seu primeiro centenário.

Eu, em nome do Pai e do Filho e do Espírito Santo, com a mão sobre o sagrado Evangelho, juro que não sou espírita e prometo que jamais hei de assistir a uma sessão, nem farei uso de receitas espíritas. Juro também que não lerei nem guardarei comigo ou com outrem livros, revistas, folhetos e jornais que defendam ou propaguem as heresias ou as superstições do Espiritismo, em qualquer de suas formas. Comprometo-me a fazer valer a minha autoridade para conservar afastados do Espiritismo os que de mim dependem. Assim prometo, assim me ajudem Deus e estes santos Evangelhos. (REB, Suplemento do fascículo de dezembro de 1956, p.139)

\section{Conflitos envolvendo o espiritismo ao longo da história: rupturas e continuidades}

Um dos estudos mais significativos realizados a respeito do Espiritismo no Brasil é o do antropólogo Emerson Giumbelli (1997). Em sua pesquisa, o antropólogo teve como um dos principais objetivos apreender os diversos discursos que foram construídos a respeito da Doutrina Espírita em seu processo de inserção no Brasil e a compreensão de como esses discursos direcionaram a consolidação das práticas espíritas, nesta perspectiva, foi analisada a trajetória da Federação Espírita Brasileira durante o período de 1884, ano de sua fundação, a 1950 .

O eixo central da pesquisa foi o Código Penal vigente entre 1890 e 1942, que em seus artigos 156, 157 e 158 abria a possibilidade de penalização do espiritismo nos "crimes contra

Oficina do Historiador, Porto Alegre, EDIPUCRS, v. 7, n. 2, jul./dez. 2014, p. 62-79. 
a saúde pública”. A partir disso o antropólogo selecionou os discursos para sua análise: os do campo médico (formulados por profissionais ou instituições médicas e psiquiátricas); jurídicos (formulados por advogados, juristas, criminalistas); jornalísticos (reportagens e enquetes feitas por repórteres de jornais da grande imprensa) e estatais (distribuídos entre os aparatos judiciários por agentes policiais, peritos, procuradores, juízes e seus aparatos assistenciais nas áreas da saúde pública e assistência social). (GIUMBELLI, 1997, p.36)

Em sua investigação Giumbelli não contemplou os discursos produzidos por instituições religiosas católicas ou protestantes a respeito do Espiritismo, salientando que

\begin{abstract}
No período delimitado para a análise, os ataques e acusações ao 'espiritismo' feitos em nome de uma determinada confissão religiosa foram reduzidos se comparados com aqueles promovidos em outros momentos. No caso do catolicismo, isso vale tanto para o período imediatamente anterior, quando seu estatuto de 'religião oficial' legitimava condenações através de pastorais e artigos na imprensa, quanto para o período imediatamente posterior, quando os ataques ao 'espiritismo' e à 'umbanda' tomam a forma de 'campanhas'. Há, entretanto, outro ponto que é tão fundamental quanto o que foi mencionado: exatamente nesse ínterim, as condenações religiosas passam a incorporar entre seus argumentos acusações forjadas em outros campos do saber, com especial destaque para o 'científico'. Ou seja, sem deixar de recorrer à acusação de 'heresia' - por ser uma traição aos ensinamentos bíblicos, por envolver práticas reprováveis como a 'necromancia' ou ainda por dar ocasião a 'manifestações demoníacas' - que permanece como uma espécie de argumento último ou específico, padres e pastores valorizam e afeiçoam-se ao discurso de médicos e psicólogos para provar a falsidade, a frivolidade ou o perigo das práticas 'espíritas'. É de esperar, portanto, que uma análise específica sobre os discursos eclesiais torne-se mais iluminada a partir dos apontamentos feitos neste trabalho.
\end{abstract}

Percebe-se que nossa análise neste artigo refere-se a período posterior aos estudos de Giumbelli, sendo a Cruzada de Defesa da Fé Católica no I Centenário do Espiritismo uma das campanhas da Igreja Católica contra o Espiritismo das quais citou o pesquisador.

Identificamos em nossa breve análise do material publicado na REB o que citou o antropólogo: os padres no período davam ênfase às acusações de "heresia" contra a Doutrina de Kardec, mas sem deixar de recorrer aos discursos médicos para deslegitimar as práticas espíritas.

Não podemos deixar de mencionar a tese do historiador Flamarion Laba da Costa, já citada anteriormente neste artigo, na qual o principal objeto de pesquisa foram os embates discursivos entre católicos e espíritas até a década de 60 do século XX a partir da análise de

Oficina do Historiador, Porto Alegre, EDIPUCRS, v. 7, n. 2, jul./dez. 2014, p. 62-79. 
periódicos e documentos. $\mathrm{O}$ autor afirma que por ter tomado uma conotação mais religiosa do que filosófica e científica em território brasileiro, os adeptos do espiritismo foram encarados como hereges pelos dirigentes e fiéis católicos. Coube aos espíritas rebater essas acusações de heresia, bruxaria e demonolatria em obras e periódicos espíritas. (COSTA, 2001, p.100101)

A partir da leitura desses dois autores, pudemos observar no material disponibilizado na REB para a Cruzada de Defesa da Fé Católica no I Centenário do Espiritismo que houveram rupturas significativas no que concerne à trajetória do movimento espírita no Brasil, mas também identificamos algumas permanências de preocupações com relação a temas caros ao movimento desde sua inserção no Brasil até os anos de 1960. Na sequência, expomos duas dessas preocupações.

\section{“Fora da caridade não há salvação": o ideal de caridade para os espíritas e como ele é tratado pelos católicos nas páginas da REB}

A máxima da caridade é um dos princípios mais propagados pelos espíritas em sua doutrina até a atualidade, o Capítulo XV do Evangelho Segundo o Espiritismo, intitulado "Fora da Caridade não há salvação" é dedicado inteiramente a este tema. ${ }^{2}$

No Brasil, conforme os estudos de Giumbelli, o princípio da caridade adquire importância essencial no início do século XX. A Federação Espírita Brasileira - FEB, foi fundada em 1884, no ano de 1889 a instituição montou um posto "mediúnico receitista" para atender gratuitamente as pessoas que procurassem o serviço, em 1900 foi instalada também uma pequena farmácia homeopática. Neste período, o serviço de consultas e distribuição de remédios era motivo de orgulho para a diretoria da FEB. (GIUMBELLI, 1997, p.128) O ideal de caridade está intimamente ligado ao aspecto religioso da Doutrina Espírita e começou a ser difundido pela FEB a partir da presidência do médico Bezerra de Menezes na instituição.

Bezerra de Menezes, presidente da FEB entre os anos de 1895 e 1900, defendia que o Espiritismo deveria compreender e divulgar o Evangelho e que as sessões de qualquer grupo

\footnotetext{
${ }^{2}$ O Evangelho Segundo o Espiritismo foi publicado por Allan Kardec pela primeira vez em 1864, mas a sua terceira edição, de 1865, é considerada pelos espíritas como a definitiva, pois, segundo eles, foi revista por Allan Kardec conforme as orientações dos Espíritos, é esta edição que a Federação Espírita Brasileira traduziu e publicou no Brasil. Nesta obra, os evangelhos canônicos da Bíblia são interpretados conforme os princípios da Doutrina Espírita, este livro é importante por trazer uma base moral ao Espiritismo.
} 
espírita deveriam também prever uma parte dedicada à caridade. (GIUMBELLI, 1997, p.114) Acentuou-se a partir de então o caráter religioso da doutrina espírita ao lado de seu caráter científico, que para os defensores do Espiritismo enquanto ciência ficava em segundo plano. Para Giumbelli, esta reivindicação do caráter religioso da Doutrina Espírita representou a escolha de uma via de legitimação das ações repressivas que o Espiritismo sofreria nos anos posteriores.

No ano de 1901 foi elaborado um novo estatuto para a FEB, com ele foi reativado um serviço de assistência aos necessitados que havia funcionado na instituição entre os anos de 1890 e 1895 e também foi garantida legitimidade ao serviço prestado nos "gabinetes clínicos" pelos "médiuns receitistas"3 desde 1889. O autor salienta que "Dos três objetivos declarados pela FEB - estudo, propaganda, filiação de grupos e promoção da caridade - era sem dúvida o último o que mais ênfase ganhava com as reformulações introduzidas pelos novos estatutos." (GIUMBELLI, 1997, p.129)

Assim, a promoção da caridade, através da Assistência aos Necessitados e dos atendimentos no "gabinete clínico" da FEB, passou a ser o principal instrumento de propaganda e de normatização da prática doutrinária, mas ao mesmo tempo essas ações desencadearam três processos criminais instaurados entre os anos de 1904 e 1905, (GIUMBELLI, 1997, p.129) nos quais a FEB era enquadrada nos Artigos 156, 157 e 158 do Código Penal e nos Artigos 250 e 251 do Regimento Sanitário, que diziam respeito a crimes contra a saúde pública no Brasil. Na argumentação de defesa do advogado da FEB foi evocado o princípio da liberdade religiosa garantido pela Constituição Federal, o que legitimava oficialmente as práticas dos espíritas enquanto práticas religiosas. A caridade, por sua vez, aparecia nesses discursos enquanto elemento essencial destas práticas religiosas.

Ao se consolidar, ao longo do século XX, enquanto instituição modeladora do Espiritismo no Brasil, a FEB indicava aos grupos que se associavam a ela que esta prática estivesse presente entre suas atividades. Observamos que até a atualidade é forte na prática de centro espíritas de todo o país, ações coletivas referendadas por este ideal.

Não é por acaso, portanto, que nas páginas da REB analisadas por nós encontramos ênfase a esta questão, tendo sido incluídos uma sugestão de programa de rádio, uma sugestão

\footnotetext{
${ }^{3}$ Médium é toda pessoa que sente a influência dos Espíritos em algum grau. No caso específico do receitista, recebe a influência do Espírito de um médico, que lhe orienta no tratamento dos doentes que o procuram. As receitas indicadas pelos médiuns receitistas geralmente eram e ainda são referendadas por um médico da instituição espírita quando necessário, que a assinava, emprestando assim seu nome e formação para que a prática se concretizasse.
} 
de rádio novela e uma sugestão de texto para publicação em jornal impresso exclusivos sobre o tema da caridade.

O "slogan" mais sedutor do Espiritismo é certamente o de que todas as religiões são boas. Seriam apenas vários caminhos para um mesmo ponto de chegada. Tudo se resumiria, afinal, em praticar a caridade. Esta isca é tão sedutora, quanto perniciosa, pois, no fundo é o indiferentismo religioso, que lentamente leva á negação das verdades. Esta propaganda encontra ótimo terreno no meio do nosso povo, caritativo, bondoso e benevolente. Basta apelar para a caridade e está conquistado. E assim, quando se trata de ajudar, não faz distinção e todos que o procuram recebem sua colaboração. E os espíritas exploram este fraco. (REB, Suplemento do fascículo de dezembro de 1956. p. 107)

Sendo a principal intenção da Igreja Católica com esses materiais "esclarecer" os católicos do país a respeito do perigo que representava o Espiritismo, grande ênfase foi dada à questão da caridade. Nos textos fica evidente a preocupação da hierarquia eclesial em demonstrar aos fiéis que não deveriam confundir-se com o discurso proferido pelos espíritas, de que a prática da caridade foi propagada e defendida por Jesus Cristo e não deveria estar presa a nenhuma denominação religiosa, mas extrapolar essas fronteiras. A este argumento os padres católicos respondiam em forma de alerta aos fiéis, que a verdadeira caridade era a salvação das almas dos necessitados e não a prática de ajuda em si (através de doações, construção de albergues, hospitais, escolas, etc.) e que essa salvação só poderia se dar através da verdadeira Igreja fundada por Jesus Cristo, a Igreja Católica.

Assim, os fiéis eram orientados a não colaborar com as obras de caridade espíritas, pois essas seriam apenas um meio de filantropia, não se constituindo na verdadeira caridade que só poderia estar relacionada às práticas católicas: “A caridade cristã é uma coisa. A filantropia é outra coisa. A caridade é fruto do amor de Deus: socorre os corpos e salva as almas.” (REB, Suplemento do fascículo de dezembro de 1956. p. 107, p.108) 


\section{Relação entre espiritismo e medicina: o espiritismo representado como caminho que leva à loucura e perigo à saúde pública}

As relações entre Espiritismo e saúde no Brasil sempre foram muito próximas. Antes mesmo da codificação d'O Livro dos Espíritos por Allan Kardec, em 1857, diversos fenômenos envolvendo a presença de espíritos eram divulgados em diferentes regiões. Foram as notícias de um tipo desses fenômenos: as mesas girantes, falantes ou rodopiantes que levaram o pedagogo francês Hippolyte Léon Denizard Rivail a interessar-se pelos acontecimentos e ao entrar em contato com eles, codificar o que os Espíritos relatavam. Fenômenos como esse, anteriores à publicação da obra de Kardec foram relatados também no Brasil.

A própria introdução do espiritismo no Brasil, alguns consideram que tenha ocorrido no ano de 1840, quando dois médicos que faziam uso da medicina homeopática e passes magnéticos para a cura de doenças - o francês Bento Mure (seu nome original era Benoit Jules), e o português João Vicente Martins - popularizaram a homeopatia aliada à aplicação de passes na então capital do Império. (COSTA, 2001, 54)

Depois da codificação da Doutrina por Kardec e a sua introdução no Brasil, houve uma grande expansão e divulgação da Doutrina Espírita a partir de sua face religiosa e da prática da caridade, tendo como principais ações filantrópicas a consulta a doentes em "gabinetes médicos" da FEB e a distribuição de remédios, principalmente homeopatias, na farmácia criada pela FEB. Esse tipo de atendimento que a FEB iniciou no final do século XIX estendeu-se para outras entidades espíritas e até hoje ainda é muito comum o atendimento de doentes por "médiuns receitistas" ou a realização de tratamentos e cirurgias espirituais. Como vimos no subtítulo anterior, esse tipo de prática levou espíritas a serem alvos de processos criminais.

Além das ações da saúde pública e policiais ligadas às práticas médicas desenvolvidas pelos espíritas, Giumbelli relata a radicalização do pensamento médico em relação ao Espiritismo nas primeiras décadas do século XX, se constituindo assim, como mais um campo em que o Espiritismo se insere de maneira conflituosa. O tema será abordado em teses, artigos e livros inteiros demonstrando que o discurso médico direcionava-se para a patologização do Espiritismo, este era tratado como prática perigosa não somente pelo contato da população com práticas não legítimas de tratamento, mas como fator que provocava transtornos mentais como a histeria, psicopatia, alienação mental. (GIUMBELLI, 1997, p.195-221)

Oficina do Historiador, Porto Alegre, EDIPUCRS, v. 7, n. 2, jul./dez. 2014, p. 62-79. 
Um contraponto a esses "ataques" dos médicos ao Espiritismo é a organização dos médicos espíritas, indivíduos que transitam em ambos os campos: médico e religioso, atuando junto a centros espíritas, sociedades e associações médico-espíritas e hospitais espíritas, endossando a prática dos médiuns ou realizando técnicas no âmbito das "medicinas paralelas" ou “complementares". (ARAUJO, 2007, p.7-11)

A organização institucional desses médicos espíritas ocorreu a partir da década de 1940. No ano de 1941 houve a fundação da Sociedade de Medicina e Espiritismo do Rio de Janeiro, mas somente em 1968 foi criada a Associação Médico-Espírita de São Paulo, estendendo a representatividade dos médicos espíritas a outras localidades do Brasil. Na década de 1990, em 1995, os médicos espíritas organizaram-se nacionalmente através da Associação Médico-Espírita do Brasil. Na atualidade são no total 36 associações médicoespíritas no país. Os primeiros registros de instituições hospitalares espíritas também datam da década de 1940, mas somente na década de 1980 e 1990 a maioria dessas instituições passou a incorporar práticas espíritas como complementação às atividades terapêuticas convencionais. Na atualidade existe um total de 39 hospitais espíritas no país. (ARAUJO, 2007, p.8-10)

Percebemos esses meios de atuação dos médicos espíritas como mais uma das formas de legitimação da Doutrina Espírita em território nacional. Enquanto na transição do século XIX para o XX os espíritas defendiam-se perante os tribunais legitimando-se através da via religiosa, com a criação de hospitais e associações os médicos espíritas procuram a legitimação de suas práticas no campo médico/científico.

Esse conflito latente no campo médico é evidenciado também nas páginas da REB, quando a Igreja se utiliza do discurso de alguns médicos psiquiatras no intuito de demonstrar que ao frequentar o Espiritismo as pessoas poderiam apresentar transtornos mentais, desta forma tentavam convencer os brasileiros a não entrar em contato com essas práticas:

Os depoimentos dos médicos não deixam dúvidas. E eles falam apoiados na experiência colhida na prática e não nas páginas dos livros. Por isso mesmo real. Para esses médicos, o Espiritismo é: "o maior fator produtor de insanos; - um grande fator de perturbações mentais e nervosas; - uma das causas predisponentes mais comuns da loucura; - uma verdadeira fábrica de loucos; - um agente provocador de delírios perigosíssimos; - as práticas espíritas avolumam proeminentemente a população dos manicômios; - é grande o número de doentes procedentes dos Centros Espíritas, que vão bater à porta do Hospício Nacional de Alienados; - entre os doentes que diariamente dão entrada no hospício, a maioria vêm dos Centros Espíritas; - os hospícios de 
psicopatas estão repletos desses casos". (REB, Suplemento do fascículo de dezembro de 1956. p.111).

Percebemos a partir desses discursos a continuidade de um pensamento médicopsiquiatra desenvolvido na primeira metade do século XX e sua apropriação pela Igreja em sua empreitada anti-espírita. Embora o Código Penal a partir de 1942 tenha sido alterado e o espiritismo descriminalizado, a Igreja ainda utilizava em seu discurso o saber médico como argumento para incentivar a volta da repressão às práticas espíritas.

Nos textos consultados sugeria-se medidas públicas de profilaxia contra a proliferação de Centros Espíritas, justificando que eram nocivos à Saúde Pública por conta do número de pessoas que ao entrar em contato com essas práticas enlouqueciam. Sugeriam abertamente que se fechassem centros alegando que "abrir um centro espírita é abrir um manicômio" ou "fechar um centro espírita é fechar um manicômio". (REB, Suplemento do fascículo de dezembro de 1956. p.111.) Além disso, sugeriam a continuidade da inconstitucionalidade do Espiritismo, rebatendo o argumento da liberdade religiosa, um dos mais utilizados pelos espíritas em sua luta por legitimidade ao longo da História:

Contra esta última conclusão espíritas e liberais levantar-se-ão, com a Constituição Brasileira em punho, para bradar que, graças a Deus, neste país democrático, há liberdade de cultos. Respondemos: Sem dúvida; mas o mesmo art. 141, $\S 7$, que nos assegura o livre exercício de cultos religiosos, acrescenta: "Salvo o dos que contrariem a Ordem Pública ou os bons costumes". Ora, o Espiritismo ou o exercício público e religioso da evocação dos mortos ou espíritos, além de ser tempo perfeitamente perdido, é contrário ao mandamento divino, e prejudicial, pernicioso, perigosíssimo, etc. Para a saúde do corpo e alma dos praticantes e assistentes e, por isso, contraria a Ordem Pública, e consequentemente, é inconstitucional. (REB, Suplemento do fascículo de dezembro de 1956. p.51).

\section{Considerações finais}

No período medieval, quando o papa Urbano II convocou os fiéis católicos para irem ao encontro dos infiéis prometendo-lhes que suas almas seriam salvas caso sofressem ao abandonar seus corpos, recomendava que a cruz fosse levada no peito e na espada de cada soldado. Aproximadamente nove séculos depois, no Brasil, os infiéis não eram os muçulmanos que haviam usurpado o Santo Sepulcro e as espadas não eram reais, mas a

Oficina do Historiador, Porto Alegre, EDIPUCRS, v. 7, n. 2, jul./dez. 2014, p. $62-79$. 
espada simbólica continuava a ser usada e a conclamação da Igreja era a mesma: Combater os infiéis, aqueles que não se submeteriam à hierarquia e dogmas católicos, ou que mesmo se submetendo poderiam querer desfrutar da liberdade religiosa e do contato com o espiritismo.

Neste ensaio pudemos demonstrar parte da dinâmica do campo religioso na ocasião do centenário do Espiritismo, as lutas simbólicas e os conflitos entre católicos e espíritas eram explícitos num país que há menos de um século havia se tornado oficialmente laico e onde a instituição católica perdia espaço na sociedade. Nesse contexto a Igreja mais uma vez utilizava-se de todas as armas possíveis para se defender da ameaça da perda de espaço na sociedade. Demonstramos aqui somente um dos lados do conflito: discursos católicos publicados na Revista Eclesiástica Brasileira manifestando-se de maneira contrária ao Espiritismo e os principais argumentos utilizados para este fim. Sabemos que o Espiritismo também empreendeu ataques, ou se defendeu, de ataques, nas páginas de seus periódicos, o que pode ser tema de análise em outro ensaio.

\section{REFERÊNCIAS BIBLIOGRÁFICAS}

ANDRADE, Solange R. A religiosidade católica no Brasil a partir da Revista Eclesiástica Brasileira. Revista Brasileira de História das Religiões. Ano I, n²2, setembro de 2008. P. 78117.

ARAUJO, Eveline Stella de. Médicos, Médiuns e Mediações: Um estudo etnográfico sobre médicos-espíritas. Dissertação. (Mestrado em antropologia). UFPR: Curitiba, 2007.

BOURDIEU, P. O poder simbólico. Rio de Janeiro: Bertrand Brasil, 1989.

A Economia das trocas linguísticas: o que falar quer dizer. São Paulo: Editora da Universidade de São Paulo, 1996.

CHARTIER, Roger. A História Cultural: entre práticas e representações. Rio de Janeiro: Difel/Bertrand Brasil, 1985.

COSTA, Flamarion Laba da. Demônios e Anjos - $O$ embate entre espíritas e católicos na República Brasileira até a década de 60 do século XX. Tese. (Doutorado em História). UFPR, Curitiba, 2001.

DALMOLIN, Débora Cristina. "Entre cruzes e anéis": A Revista Eclesiástica Brasileira e as representações de família (1941-1965). Dissertação. (Mestrado em História). UFPR, Curitiba, 2010.

GIUMBELLI, Emerson Alessandro. O cuidado dos mortos: uma história da condenação e legitimação do Espiritismo. Rio de Janeiro: Arquivo Nacional, 1997.

Oficina do Historiador, Porto Alegre, EDIPUCRS, v. 7, n. 2, jul./dez. 2014, p. 62-79. 
SCHLENKER, Rodrigo. A representação da Revista Eclesiástica Brasileira como um modelo de discurso religioso. ANAIS DO III ENCONTRO NACIONAL DO GT

HISTÓRIA DAS RELIGIÕES E DAS RELIGIOSIDADES - ANPUH - Questões teórico metodológicas no estudo das religiões e religiosidades. IN: Revista Brasileira de História das Religiões. Maringá (PR) v. III, n.9, jan/2011. ISSN 1983 - 2859. Disponível em http://www.dhi.uem.br/gtreligiao/pub.html. Acesso em 11 de dezembro de 2013.

\section{Fontes:}

Revista Eclesiástica Brasileira dos anos de 1941 e 1956.

ARTIGO ENVIADO EM: 20/03/2014

ACEITO PARA PUBLICAÇÃO EM: 22/10/2014

Oficina do Historiador, Porto Alegre, EDIPUCRS, v. 7, n. 2, jul./dez. 2014, p. 62-79. 